\title{
UNIVERSITY LECTURERS' VIEWS ON DISTANCE EDUCATION DURING THE COVID-19 PANDEMIC: UKRAINIAN-LATVIAN COMPARATIVE STUDIES
}

\author{
Oleksandr Malykhin \\ Institute of Pedagogy of the National Academy of Educational Sciences of Ukraine, Ukraine \\ Svetlana Usca \\ Rezekne Academy of Technologies, Latvia
}

Nataliia Aristova

Institute of Pedagogy of the National Academy of Educational Sciences of Ukraine, Ukraine

\begin{abstract}
The main purpose of the study was to compare and contrast Ukrainian and Latvian university lecturers' views on distance education (teaching and learning) caused by the sudden interruption of the face-to face instruction due to the COVID-19 pandemic. The study was also targeted at investigating university lecturers' readiness to respond to the educational challenges during the pandemic. The international team of researchers set up a web-based questionnaire aimed at self-assessing Ukrainian and Latvian university lecturers' digital literacy knowledge and skills and finding out their attitudes towards current educational changes. Having absolutely identical content the web-based questionnaire was presented in the Ukrainian, Latvian and English languages. The research sample which was selected with the use of a voluntary response sampling technique consisted of 60 university lecturers from Kyiv National University of Technologies and Design (Kyiv, Ukraine), Taras Shevchenko National University of Kyiv (Kyiv, Ukraine), National Aviation University (Kyiv, Ukraine), Rezekne Academy of Technologies (Rezekne, Latvia). Qualitative data analysis covered a conscientious summing-up of the information received, displaying the processed data in the form of tables and pie charts, comparing and generalizing the data received in Ukraine and Latvia, discussing the obtained findings and making logical conclusions how to cope with educational challenges.

Keywords: distance teaching and learning, educational challenges caused by the COVID-19 pandemic, face-to-face instruction, higher education institutions, Latvia, Ukraine, university lecturers, university lecturers' digital literacy.
\end{abstract}

\section{Introduction}

Conditions of life in today's globalized society distinguished by rapid development of science and technology make high demands on professional training of future specialists of different spheres who will serve their country 
and the worldwide community as a whole. Around the globe, higher education is aimed at fulfilling the educational needs of new entrants into the labour market and providing them with professional skills and expertise and developing key competences for lifelong learning. To achieve these goals higher education institutions along with degree programs that require traditional face-to-face instruction offer a great variety of distance degree programs that enable students to study online at a pace that can fit their lifestyle. With the rise of information technologies, more and more scholars and practitioners are considering distance education as an effective means that brings about new teaching and learning opportunities for both university lecturers and students (Bozkurt et al., 2015; Leontyeva, 2018; Malykhin, Aristova \& Dybkova, 2019; Malykhin et al., 2020; Malykhin, Aristova \& Kovalchuk, 2019; Saba, 2000). Thus, V. Arkorful and $\mathrm{N}$. Abaidoo believe that one of the key advantages of distance education is that "it makes use of technological tools to enable learners study anytime and anywhere" (2015, p. 403). According to M. Sadeghi, distance education "might not be the best choice for every student seeking to pursue a college degree or university program but the list of advantages seems to outweigh the list of disadvantages" (Sadeghi, 2019, p. 83). The similar idea can be seen very clearly in the works by M. Bušelić (2012), M. Farajollahi et al. (2010), E. Murphy \& M. Rodríguez-Manzanares (2012). M. Bušelić believes that being used for a variety of purposes, distance education "offers a myriad of advantages which can be evaluated by technical, social and economic criteria" (Bušelić, 2012, p. 25). Moreover, regarding distance education as "a contributing force to social and economic development" (Bušelić, 2012, p. 25), M. Bušelić thinks that it is "an essential part of the mainstream of educational systems in both developed and developing countries" (Bušelić, 2012, p. 25). The researcher also associates distance education with "a field of education that focuses on teaching methods and technology with the aim of delivering teaching, often on an individual basis, to students who are not physically present in a traditional educational setting such as a classroom” (Bušelić, 2012, p. 24).

The COVID-19 pandemic has dramatically altered the accustomed assumption about provision of educational services and organization of educational process in higher education institutions worldwide. After the introduction of physical-distancing measures, including closing academic institutions, universities had to respond quickly and the full transition to distance teaching and learning seemed to be the only solution at that time. But as time went on, distance education, such as it was, proved incapable of replacing faceto-face instruction completely and, what is more, of equipping future entrants into the labour market with a full range of key competences for lifelong learning, professional skills and expertise they need to adapt quickly to new working environment and to impact their performance in the workplace. 
It should be also noted that despite the fact that distance education has its indisputable advantages in comparison with other ways of innovative teaching and learning, much remains to be reevaluated and taken into account to bring the training in higher education institutions into line with new realities of life caused by the COVID-19 pandemic. In this respect, international collaborative studies can be of invaluable assistance in this process (Blayone et al., 2020; Mykhailenko et al., 2020; Žogla, Ušča, \& Mykhailenko, 2020). This reflects the fact that despite the general trend towards implementing distance education for training students of different specialties, each country can offer its own positive initiatives since it faces diverse challenges and finds its own solutions, corresponding to its economic development. The analysis, comparison and generalization of educational experience in dealing with educational consequences of the COVID-19 pandemic already gained by Ukrainian and Latvian university lecturers could become invaluable for overcoming existing problems and emphasizing the directions necessary for further improvement of educational process in higher education institutions, enhancement of educational services delivery and, what is more important, formation of completely new skills connected with distant teaching and learning among university lecturers, development of their professional, pedagogical and digital culture and competence. In this regard, the main purpose of the study was to compare and contrast Ukrainian and Latvian university lecturers' views on distance teaching and learning caused by the sudden interruption of the face-to face instruction and the closure of higher education institutions due to the COVID-19 pandemic, on the one hand, and on their readiness to respond to the educational challenges during the pandemic, on the other.

\section{Research Methodology Research Sample}

Subjects of the study were Ukrainian and Latvian university lecturers. The research sample was selected with the use of a voluntary response sampling technique and contained 60 university lecturers from Ukrainian and Latvian higher education institutions. The Ukrainian study sample consisted of 34 university lecturers from Kyiv National University of Technologies and Design (Kyiv, Ukraine), Taras Shevchenko National University of Kyiv (Kyiv, Ukraine) and National Aviation University (Kyiv, Ukraine). The Latvian study sample contained 26 university lecturers from Rezekne Academy of Technologies (Rezekne, Latvia). The survey was carried out in September-November 2020. 
Malykhin et al., 2021. University Lecturers'Views on Distance Education During the Covid-19 Pandemic: Ukrainian-Latvian Comparative Studies

\section{Instrument and Procedure}

Data collection instrument included a web-based questionnaire developed by the international team of researchers from Ukraine and Latvia using Google Forms. The main purpose of developing the web-based questionnaire was to collect and compare information concerning main educational challenges university lecturers face in two countries, namely Ukraine and Latvia. The webbased questionnaire containing five obligatory questions was developed in three languages, namely Ukrainian, Latvian and English. Five obligatory questions were aimed at finding out Ukrainian and Latvian university lecturers' attitudes towards educational changes occurred as a result of the transition of the face-toface learning in the distance learning format as well as assessing their digital knowledge and skills. For the main purpose of our study we considered the following questions:

1. Can you list what has changed for worse with the sudden and unpredicted interruption of the face-to face instruction and the closure of universities due to the COVID-19 pandemic?

2. Can you offer your own hierarchy of problems and difficulties caused by the COVID-19 pandemic that are hard to overcome now and in the nearest future (from the most serious to less serious)?

3. Can you list what has changed for better with the sudden and unpredicted interruption of the face-to face instruction and the closure of universities due to the COVID-19 pandemic?

4. Can you hierarchize positive changes connected with transition of the face-to-face instruction in the distance learning format that have already happened in your life?

5. What is your attitude towards distance teaching and learning caused by unpredicted global changes including the COVID-19 pandemic?

Moreover, since we were interested in reaching objective and reliable conclusions we included four questions concerning demographic information of Ukrainian and Latvian lecturers. The demographic distribution of Ukrainian and Latvian research samples is presented in Table 1. 
Proceedings of the International Scientific Conference. Volume V, May $28^{\text {th }}-29^{\text {th }}, 2021.145-157$

Table 1 Ukrainian and Latvian Samples Demographics

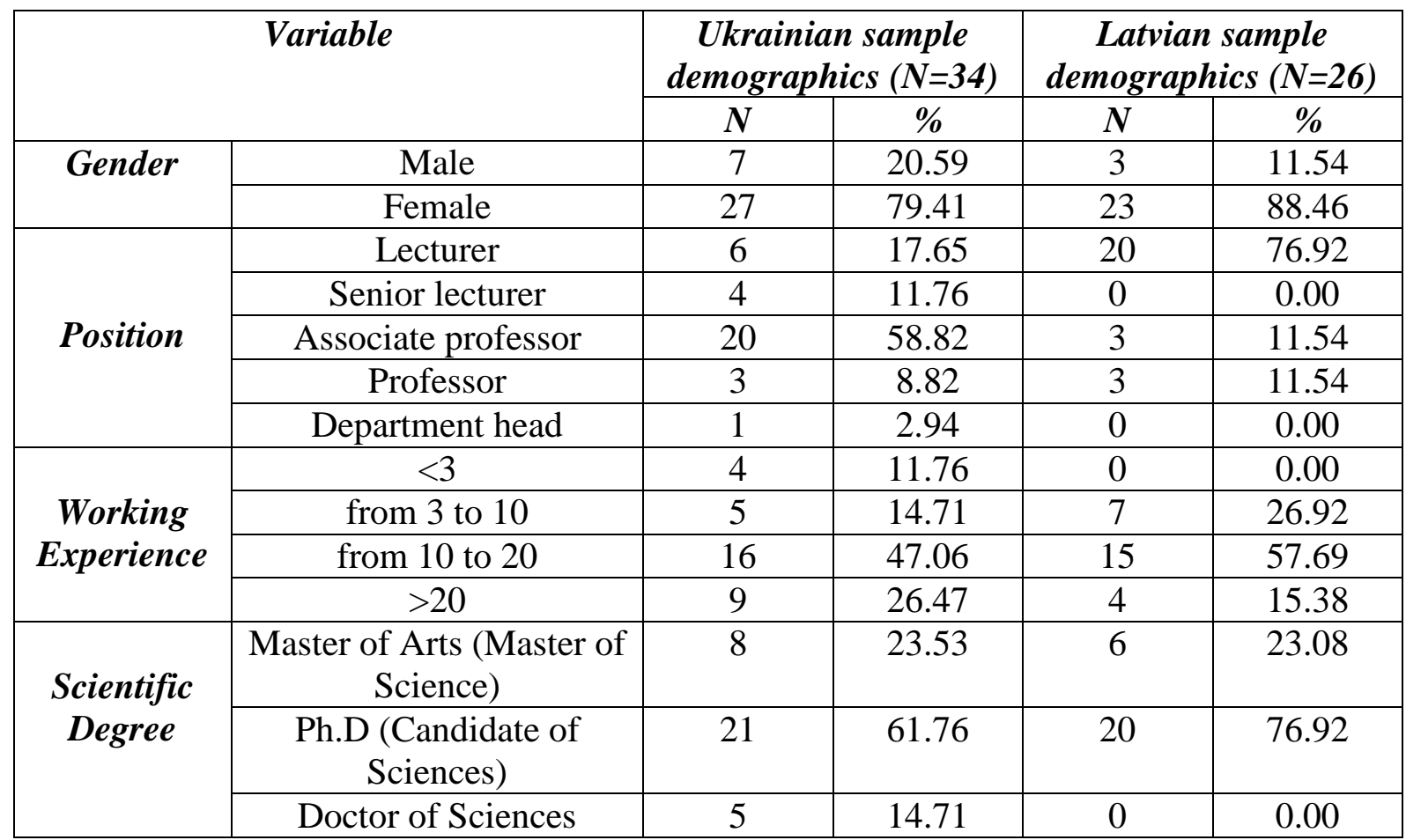

Source: own study

$N=60$

\section{Data Analysis}

Qualitative data analysis covered a conscientious summing-up of the information received, displaying the processed data in the form of pie charts, comparing and generalizing the data received in Ukraine and Latvia, discussing and sharing findings with academic community.

\section{Results and Discussion}

The main aim of the first question was to find out what, in university lecturers' opinion, changed for worse with the sudden and unpredicted interruption of the face-to face instruction and the closure of universities due to the COVID-19 pandemic. The obtained findings showed that despite a large body of theory and practice regarding distance teaching and learning (Arkorful, \& Abaidoo, 2015; Bozkurt et al., 2015; Farajollahi, 2010; Leontyeva, 2018; Murphy \& Rodríguez-Manzanares, 2012; Saba, 2000; Sadeghi, 2019), in real circumstances of transition to distance education many negative educational changes occurred. We allege from the results obtained that all the negative educational challenges which cause a serious concern for Ukrainian and Latvian university lecturers were almost identical. The main difference was the extent of 
Malykhin et al., 2021. University Lecturers'Views on Distance Education During the Covid-19 Pandemic: Ukrainian-Latvian Comparative Studies

their influence over their professional responsibilities. Table 2 demonstrates major negative educational changes caused by the COVID-19 pandemic in Latvian university lecturers’ opinion.

Table 2 Major Negative Educational Changes Caused by the COVID-19 Pandemic in Latvian University Lecturers' Opinion

\begin{tabular}{|l|c|c|}
\hline \multicolumn{1}{|c|}{ A list of things that changed for worse } & N & \% \\
\hline The increase in workload & 24 & 92.31 \\
\hline Students' inability to fully acquire practical skills & 21 & 80.77 \\
\hline $\begin{array}{l}\text { The increase of various bureaucratic online-meetings and in the number } \\
\text { of documents }\end{array}$ & 20 & 76.92 \\
\hline The reduced quality of educational process & 17 & 65.38 \\
\hline Irregular working hours & 15 & 57.69 \\
\hline The lack of emotional contact with students & 12 & 16.15 \\
\hline The decrease in face-to-face interaction & 11 & 42.31 \\
\hline Lack of students' confidence to reach the expected outcomes & 8 & 30.77 \\
\hline $\begin{array}{l}\text { Difficulties in using individual approach, especially in creative/research } \\
\text { work }\end{array}$ & 4 & 15.38 \\
\hline $\begin{array}{l}\text { Difficulties in using complex programs typically unavailable on } \\
\text { students' personal computers }\end{array}$ & 3 & 11.54 \\
\hline
\end{tabular}

Source: own study $(N=26)$

Table 3 shows the Ukrainian university lecturers' opinion on negative educational changes caused by the COVID-19 pandemic.

Table 3 Negative Educational Changes Caused by the COVID-19 Pandemic in Ukrainian University Lecturers' Opinion

\begin{tabular}{|l|c|c|}
\hline \multicolumn{1}{|c|}{ A list of things that changed for worse } & N & \% \\
\hline $\begin{array}{l}\text { University lecturers' and students' inadequate technical capabilities } \\
\text { (the lack of high-speed Internet and poor quality of free software) }\end{array}$ & 27 & 79.41 \\
\hline The lack of proper digital knowledge and skills to work remotely & 25 & 73.53 \\
\hline The increase in workload & 24 & 70.59 \\
\hline $\begin{array}{l}\text { The low level of digital competence (among both students and } \\
\text { university teachers) }\end{array}$ & 22 & 64.71 \\
\hline Overwhelming emotional and/or psychological pressure & 21 & 61.76 \\
\hline Students' inability to work independently & 20 & 58.82 \\
\hline $\begin{array}{l}\text { The lack of emotional contact with students (it is difficult to understand } \\
\text { what students understand from the content and what not) }\end{array}$ & 19 & 55.88 \\
\hline The reduced quality of educational process & 16 & 47.06 \\
\hline The decrease in face-to-face interaction & 14 & 41.18 \\
\hline $\begin{array}{l}\text { Poor technical, organizational and content support of university's } \\
\text { digital teaching and learning environment }\end{array}$ & 12 & 35.29 \\
\hline
\end{tabular}

Source: own study $(N=34)$ 
Table 4 indicates the Ukrainian and Latvian university lecturers' responses concerning the hierarchy of problems and difficulties that were hard to overcome rapidly (from the most serious to less serious) after the introduction of physical-distancing measures.

Table 4 The Hierarchy of Problems and Difficulties Caused by the COVID-19 Pandemic According to Ukrainian and Latvian University Lecturers

\begin{tabular}{|c|c|c|c|c|c|}
\hline \multicolumn{3}{|c|}{$\begin{array}{l}\text { Latvian university lecturers' } \\
\text { responses }\end{array}$} & \multicolumn{3}{|c|}{ Ukrainian university lecturers’ responses } \\
\hline $\begin{array}{c}\text { Identified problems and } \\
\text { difficulties }\end{array}$ & $\mathbf{N}$ & $\%$ & $\begin{array}{c}\text { Identified problems and } \\
\text { difficulties }\end{array}$ & $\mathbf{N}$ & $\%$ \\
\hline $\begin{array}{l}\text { Delivery of educational } \\
\text { content to students remotely }\end{array}$ & 22 & 84.62 & Internet connection problems & 27 & 79.41 \\
\hline $\begin{array}{l}\text { Low level of digital } \\
\text { competence }\end{array}$ & 19 & 73.08 & $\begin{array}{l}\text { Increase in workload (Much } \\
\text { time spent on making online } \\
\text { lectures and training courses) }\end{array}$ & 24 & 70.59 \\
\hline $\begin{array}{l}\text { Organization of active } \\
\text { learning }\end{array}$ & 14 & 53.85 & $\begin{array}{l}\text { Insufficient level of own } \\
\text { digital competence }\end{array}$ & 23 & 67.65 \\
\hline $\begin{array}{l}\text { Inability to apply appropriate } \\
\text { teaching methods digitally }\end{array}$ & 14 & 53.85 & $\begin{array}{l}\text { Lack of previous experience to } \\
\text { deliver educational content to } \\
\text { students in distance-learning } \\
\text { format }\end{array}$ & 22 & 64.71 \\
\hline $\begin{array}{l}\text { Lack of a single platform } \\
\text { (Team, Moodle, Luis are } \\
\text { used) }\end{array}$ & 13 & 50.00 & $\begin{array}{l}\text { Absence of standard } \\
\text { requirements to regulate } \\
\text { working hours }\end{array}$ & 20 & 58.82 \\
\hline Internet connection problems & 12 & 46.15 & $\begin{array}{l}\text { Inability to organize effective } \\
\text { interaction between students in } \\
\text { distance format }\end{array}$ & 17 & 50.00 \\
\hline $\begin{array}{l}\text { Insufficient level of students' } \\
\text { digital competence }\end{array}$ & 11 & 42.31 & $\begin{array}{l}\text { A wide range of } \\
\text { telecommunications } \\
\text { applications to work with }\end{array}$ & 14 & 41.18 \\
\hline $\begin{array}{l}\text { Failure to use licensed } \\
\text { programs intended for the } \\
\text { study process (SPSS, } \\
\text { COREL, etc.) at home }\end{array}$ & 10 & 38.46 & $\begin{array}{l}\text { High rates of procrastination } \\
\text { among students }\end{array}$ & 13 & 38.24 \\
\hline Copyright issues & 9 & 34.62 & $\begin{array}{l}\text { Lack of social interaction } \\
\text { between colleagues }\end{array}$ & 12 & 35.29 \\
\hline Technical support of students & 9 & 34.62 & $\begin{array}{l}\text { Insufficient level of students' } \\
\text { digital competence }\end{array}$ & 11 & 32.35 \\
\hline
\end{tabular}

Source: own study $(N=60)$

As we can see main problems and difficulties Ukrainian and Latvian university had to face after the transition of face-to-face instruction into the distance learning format were rather identical. Thus, according to $79.41 \%$ of 
Malykhin et al., 2021. University Lecturers'Views on Distance Education During the Covid-19 Pandemic: Ukrainian-Latvian Comparative Studies

Ukrainian respondents, the main problem caused by the COVID-19 pandemic, was the poor Internet connection which made it almost impossible to deliver learning material effectively. $70.59 \%$ of Ukrainian respondents and $46.15 \%$ of Latvian respondents considered the increase in workload as one of the main challenges caused by the COVID-19 pandemic. Naming this problem, some Ukrainian respondents (58.82\%) explained that they associated the increase in workload with the lack of standards, rules and legal documentations that regulate their working hours both at the national and institutional levels. That affected the time they spent on making online lectures and training courses, grading papers, checking homework etc. It should be also noted that for $67.65 \%$ of Ukrainian respondents and $73.08 \%$ of Latvian respondents the main problem in delivering learning material was the insufficient level of their digital competence. What is more, $64.71 \%$ of Ukrainian respondents and $53.85 \%$ of Latvian respondents noted that the lack of previous experience to deliver educational content to students in distance-learning format made it almost impossible to apply appropriate teaching methods digitally and it took time to develop the necessary digital skills. $41.18 \%$ of Ukrainian respondents noted that the main problem they faced was a wide range of telecommunications applications to work with and that they had to use several telecommunications apps working with different groups of students while the necessity to use various platforms to deliver educational material was of a major concern for many Latvian university lecturers $(50.00 \%)$. The main difficulty of working in the distance learning format for $38.24 \%$ of Ukrainian respondents was high rates of procrastination among students which negatively affect their performance level. $35.29 \%$ of Ukrainian respondents indicated that the main difficulty was connected with the lack of social interaction between colleagues. $32.25 \%$ of Ukrainian respondents and $42.31 \%$ of Latvian respondents found the insufficient level of students' digital competence the worst problem they faced.

Tables 5 presents the Ukrainian university lecturers' responses concerning positive changes connected with the transition of the face-to-face instruction in the distance learning format due to the COVID-19 pandemic.

Table 5 Ukrainian University Lecturers' Responses Concerning Positive Changes Amid Covid-19 Pandemic

\begin{tabular}{|l|c|}
\hline \multicolumn{1}{|c|}{ Ukrainian respondents' responses } & N \\
\hline Opportunity to gain completely new experience & 22 \\
\hline Opportunity to improve digital skills & 19 \\
\hline Saving money & 16 \\
\hline No commuting & 15 \\
\hline No positive changes & 8 \\
\hline
\end{tabular}

Source: own study $(N=34)$ 
Tables 6 presents the Latvian university lecturers' responses concerning positive changes connected with the transition of the face-to-face instruction in the distance learning format due to the COVID-19 pandemic.

\section{Table 6 Latvian University Lecturers' Responses Concerning Positive Changes Amid} Covid-19 Pandemic

\begin{tabular}{|l|c|}
\hline \multicolumn{1}{|c|}{ Latvian respondents' responses } & N \\
\hline Improved digital skills & 25 \\
\hline $\begin{array}{l}\text { The pandemic made it possible to see more clearly the strengths and weaknesses of } \\
\text { education }\end{array}$ & 16 \\
\hline $\begin{array}{l}\text { Opportunity not to spend time for changing places in order to participate in various } \\
\text { events immediately switching from one to another }\end{array}$ & 14 \\
\hline $\begin{array}{l}\text { Encouragement to improve personal professional activity, learn new teaching and } \\
\text { learning methods }\end{array}$ & 13 \\
\hline Beginning of technological revolution & 12 \\
\hline Interesting experience for both lecturers and students & 11 \\
\hline
\end{tabular}

Source: own study $(N=26)$

According to the obtained results, among the positive changes caused by the introduction of physical-distancing measures, Ukrainian respondents noted the opportunity to gain completely new experience (64.71\%), to improve digital skills (55.88\%), to save money (47.06\%) and not to commute to work (44.12\%). $23.53 \%$ of Ukrainian respondents did not see any positive changes from imposing measures, including closing higher education institutions. As for Latvian respondents, the most important positive change was connected with the opportunity to improve their digital skills (96.15\%). For $61.54 \%$ of Latvian respondents the transition of face-to-face instruction to distance teaching and learning made it possible to see more clearly the strengths and weaknesses of education. 53.85\% of Latvian respondents regarded compulsory measures connected the implementation of distance education and the provision of various meetings, seminars and workshops online with the opportunity not to spend time for changing places in order to participate in various events and $50.00 \%$ of them regarded these measures as a kind of encouragement to improve personal professional activity and to learn new teaching and learning methods. 46.15\% of Latvian respondents believed that the full transition to distance education marked the beginning of a technological revolution that had been planned for a long time but could not be started for many objective reasons. $42.31 \%$ of Latvian respondents replied that the replacement of face-to-face instruction by online one became interesting experience for both lecturers and students.

The last question was aimed at figuring out university lecturers' attitude towards distance teaching and learning caused by unpredicted global changes 
Malykhin et al., 2021. University Lecturers'Views on Distance Education During the Covid-19 Pandemic: Ukrainian-Latvian Comparative Studies

including the COVID-19 pandemic. The survey results indicate that the number of Ukrainian university lecturers who showed either a positive or a negative attitude towards distance teaching and learning caused by unpredicted global changes including the COVID-19 pandemic was equally divided whereas the Latvian respondents' responses were slightly different. Thus, the positive attitude was shown by eleven Ukrainian university lecturers (32.35\%). The same number of Ukrainian university lecturers (32.35\%) expressed the negative attitude towards distance learning and teaching. Twelve Ukrainian university lecturers (35.30\%) found it difficult to answer the question (Fig.1).

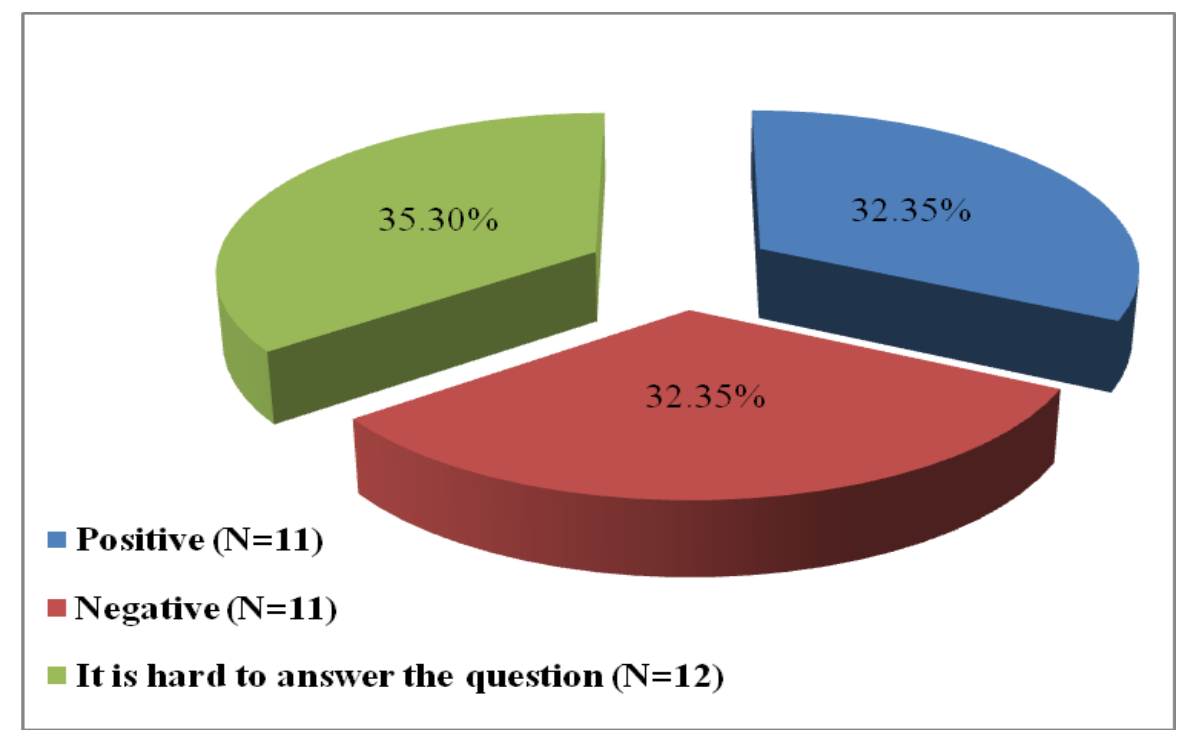

Figure 1 Ukrainian University Lecturers' Attitude towards Distance Education Caused by the Covid-19 Pandemic

Source: own elaboration on the basis of data obtained during research

As for Latvian university lecturers, five of them (19.23\%) demonstrated a positive attitude towards distance teaching and learning while negative attitude was expressed by four university lecturers (15.38\%). What was quite unexpected was that seventeen Latvian university lecturers (65.39\%) found it difficult to answer this question (Fig.2). Thus, basing on the results obtained we can assume that the Ukrainian university lecturers were more categorical in their judgments concerning the full transition to distance education. According to responses to the Web-questionnaire, we attribute it mainly to technical and material ability of higher education institutions to provide efficient and uninterrupted educational services to students during the COVID-19 pandemic, the level of university teachers' and students' digital competence, their material well-being and a significant increase in the workload. 


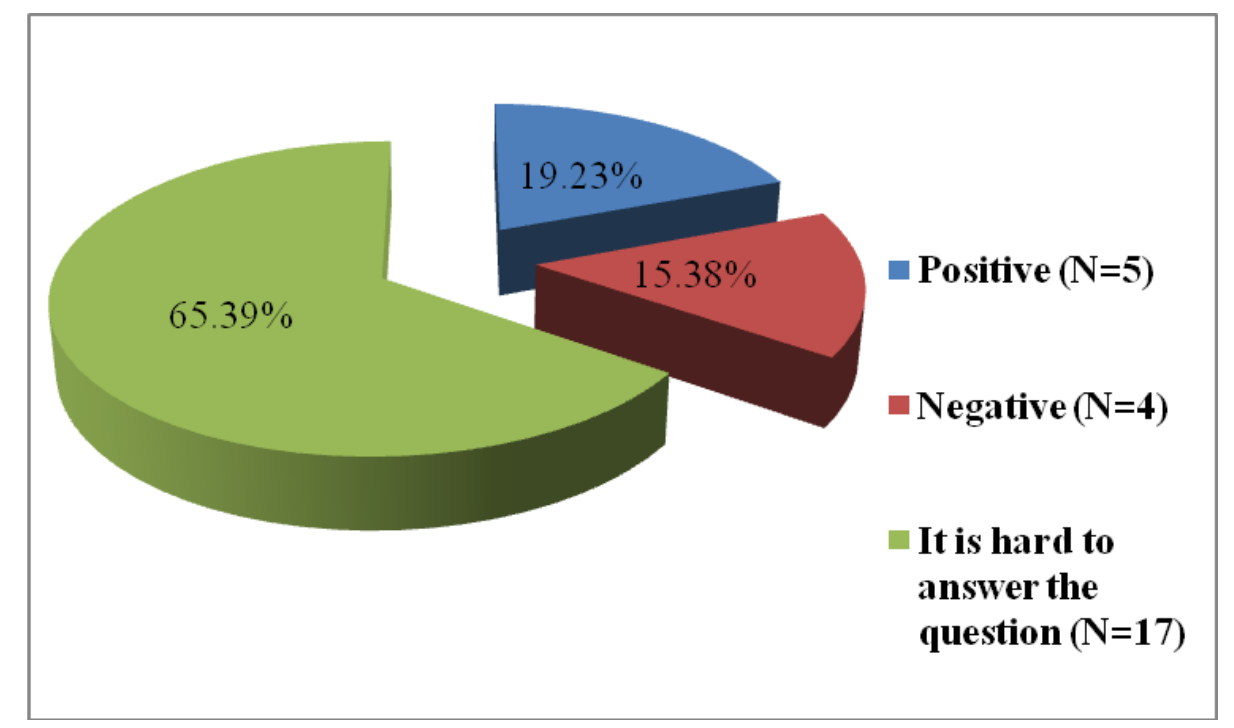

Figure 2 Latvian University Lecturers' Attitude towards Distance Education Caused by the Covid-19 Pandemic

Source: own elaboration on the basis of data obtained during research

\section{Conclusions}

In conclusion, we should note that despite the considerable experience already gained in the field of using open educational resources and telecommunications applications for online and offline educational content delivery, world community first confronted the closures of higher education institutions and the replacement of face-to-face instruction with distance education. The conducted Ukrainian-Latvian studies have revealed many problems and difficulties in relation to distance teaching and learning caused by the COVID-19 pandemic. We can assume that the problems and difficulties Ukrainian and Latvian university lecturers faced could be divided into two groups, namely, internal and external. The group of internal problems and difficulties included the insufficient level of digital competence of both students and lecturers; the inability to apply appropriate teaching methods digitally, to organize active learning online effectively and to work using different online platforms, lack of social interaction between colleagues, high rates of procrastination among students etc. Taking into account the obtained results, we can conclude that once the internal problems and difficulties were understood, both Ukrainian and Latvian university lecturers took all steps to solve them independently. Unlike internal problems and difficulties, external ones could not be solved by university lecturers or students alone. Special actions were required (and are still required) at the international, national and institutional levels to help university lecturers deal with the identified problems effectively. This 
Malykhin et al., 2021. University Lecturers'Views on Distance Education During the Covid-19 Pandemic: Ukrainian-Latvian Comparative Studies

group included the problems connected with the poor Internet connectivity, absence of standard requirements to regulate working hours at the international and national levels, comprehensive technical support of both teachers and students, failure to use licensed programs intended for the study process (SPSS, COREL, etc.) at home, copyright issues etc. But, to sum up, we should note that having to adapt quickly to entirely new online modes of delivery of educational material by means of the Internet and different telecommunications applications and taking all steps to improve the level of their digital competence university lecturers in Ukraine and Latvia demonstrated full readiness and willingness to fight the identified negative educational challenges caused by the Covid-19 pandemic and to improve their professional skills and expertise.

\section{References}

Arkorful, V. \& Abaidoo, N. (2015). The Role of E-learning, advantages and disadvantages of its adoption in higher education. International Journal of Instructional Technology and Distance Learning, 12(1), 29-42.

Blayone, T.J.B., Mykhailenko, O., Usca, S., Abuze, A., Romanets, I., \& Oleksiiv, M. (2020). Exploring technology attitudes and personal-cultural orientations as student readiness factors for digitalised work. Higher Education, Skills and Work-Based Learning. DOI: https://doi.org/10.1108/HESWBL-03-2020-0041

Bušelić, M. (2012). Distance Learning - Concepts and Contributions. Oeconomica Jadertina, 1, 23-34.

Bozkurt, A., Akgun-Ozbek, E., Yilmazel, S., Erdogdu, E., Ucar, H., Guler, E., Sezgin, S., Karadeniz, A., Sen-Ersoy, N., Goksel-Canbek, N., Dincer, G., Ari, S., \& Aydin, C. H. (2015). Trends in Distance Education Research: A Content Analysis of Journals 20092013. The International Review of Research in Open and Distributed Learning, 16(1), 330-363. DOI: https://doi.org/10.19173/irrodl.v16i1.1953

Farajollahi, M., Zare, H., Hormozi, M., Sarmadi, M. R., \& Zarifsanaee, N. (2010). A Conceptual Model for Effective Distance Learning in Higher Education. Turkish Online Journal of Distance Education, 11(3), 63-77.

Leontyeva, I. A. (2018). Modern Distance Learning Technologies in Higher Education: Introduction Problems. EURASIA Journal of Mathematics, Science and Technology Education, 14(1), em1578. DOI: https://doi.org/10.29333/ejmste/92284

Malykhin, O., Aristova, N., \& Dybkova, L. (2019). Developing Future English Teachers' Overall Communicative Language Ability: Open Educational Resources Usage. Revista Romaneasca pentru Educatie Multidimensionala, 11(4 Suppl. 1), 134-155. DOI: 10.18662/rrem/182

Malykhin, O., Aristova, N., \& Kovalchuk, V. (2019). Investigation into Open Educational Resources for Learning English in Developing Future Philologists' Instrumental Values. Society. Integration. Education. Proceedings of the International Scientific Conference, 3, 512-526. DOI: https://doi.org/10.17770/sie2019vol3.3833

Malykhin, O., Aristova, N., Kovalchuk, V., Opaliuk, T. \& Yarmolchuk, T. (2020). Higher School Teachers' Digital Competence: Strategies for Self-Assessment and Improvement. Society. Integration. Education. Proceedings the International Scientific Conference, 2, 41-51. DOI: http://dx.doi.org/10.17770/sie2020vol2.4901 
Murphy, E. \& Rodríguez-Manzanares, M. (2012). Rapport in Distance Education. International Review of Research in Open and Distributed Learning, 13(1), 167-190. DOI: https://doi.org/10.19173/irrodl.v13i1.1057

Mykhailenko, O., Blayone, T.J.B., Usca, S., Kvasovskii, O., \& Desyatnik, O. (2020). Optimism, interest and opportunity: Comparing attitudes of university students in Latvia and Ukraine toward IT learning and work. Compare: A Journal of Comparative and International Education. DOI: https://doi.org/10.1080/03057925.2020.1843999

Saba, F. (2000). Research in Distance Education: A Status Report. International Review of Research in Open and Distance Learning, 1(1). DOI: https://doi.org/10.19173/ irrodl.v1i1.4

Sadeghi, M. (2019). A Shift from Classroom to Distance Learning: Advantages and Limitations. International Journal of Research in English Education, 4(1), 80-88. DOI: 10.29252/ijree.4.1.80

Žogla, I., Ušča, S., \& Mykhailenko, O. (2020). Capability Approach in Tertiary TechnologyEnriched Education: Looking for new directions. Rural Environment. Education. Personality, 13, 200-209. DOI: 10.22616/REEP.2020.024 